\title{
Study of Cause and Effect Relationship among Yield, Yield Contributing and Quality Traits in Cotton (Gossypium hirsutum L.)
}

\author{
K.V. Siva Reddy ${ }^{1}$, B. Balakrishna ${ }^{2 *}$ and V. Chenga Reddy ${ }^{3}$ \\ ${ }^{1}$ Agricultural Research Station, Acharya N G Ranga Agricultural University, \\ Amaravathi, Guntur-522 020, Andhra Pradesh, India \\ ${ }^{2}$ Dr Y S R Horticultural University, Venkataramannagudem-534101, Andhra Pradesh, India \\ ${ }^{3}$ All India Co-ordinated Cotton Improvement Project, Regional Agricultural Research Station, \\ Acharya N G Ranga Agricultural University, Lam, Guntur-522 034, Andhra Pradesh, India
}

*Corresponding author

\begin{tabular}{|c|c|}
\hline & A B S T R A C T \\
\hline $\begin{array}{l}\text { Upland cotton, } \\
\text { Character } \\
\text { association, Path } \\
\text { analysis }\end{array}$ & \multirow{3}{*}{$\begin{array}{l}\text { The present study was conducted during kharif-2014-15 with } 37 \text { genotypes to understand } \\
\text { the association among the yield, yield attributing and quality traits in cotton. The } \\
\text { experiment revealed that seed cotton yield had positive association with number of bolls } \\
\text { per plant, boll weight and lint yield at both genotypic and phenotypic levels. Path analysis } \\
\text { revealed that number of boll per plant and boll weight was showing negative direct effects } \\
\text { at genotypic level and positive direct effects at phenotypic level. So that restriction } \\
\text { selection is advisable for improving seed cotton yield. Whereas, the important quality } \\
\text { parameters like } 2.5 \% \text { span length and bundle strength recorded negative association with } \\
\text { seed cotton yield but bundle strength showed positive direct effects direct selection for this } \\
\text { trait may improve seed cotton yield. Whereas, } 2.5 \% \text { span length registered negative direct } \\
\text { effects, hence selection for increased yield may leads to decrease in } 2.5 \% \text { span length. }\end{array}$} \\
\hline Article Info & \\
\hline $\begin{array}{l}\text { Accepted: } \\
\text { 15 May } 2019 \\
\text { Available Online: } \\
\text { 10 June } 2019\end{array}$ & \\
\hline
\end{tabular}

\section{Introduction}

Cotton (Gossypium hirsutum L.) is the one of the important fibre crops all over world. Among the cultivated genotypes hirsutum varieties/hybrids are more as they are high yielders when compared to remaining three cultivated species. In any crop improvement program selection or development of new genotypes/hybrids are two important activities, during this process there is a lot of need to understand the genetic relationship among those characters. Especially in cotton both quantitative as well as qualitative characters should be taking into consideration. So that before selection there is a great need to understand the correlation between different quantitative characters and fibre quality characters. After understanding correlation between any two traits still there is further need to study whether the positive or negative relationship between any traits is due to direct effects of those characters or due to indirect effects through other character 
(Bayyapu Reddy et al., 2015). Path analysis is one of the biometrical techniques to know fore said direct and indirect effects as it splits the correlation coefficient into direct and indirect effects. Hence, the present investigation conducted to select better genotypes from available cotton germplasm.

\section{Materials and Methods}

The present study was conducted during kharif-2014-15 at Regional Agricultural Research Station, Lam. There are 37 genotypes collected from different parts of country was planted in Randomized Block Design with three replications by adopting $105 \mathrm{~cm} \times 60 \mathrm{~cm}$ regularly followed spacing. All recommended agronomic package of practices for cotton crop were followed for raising a good crop. The data was recorded on five randomly selected plants from each replication from each treatment. Data was analyzed for analysis of variance as per Cochran and Cox (1950) and Correlation coefficients between different characters were worked out as per Singh and Chaudhary (1985). Genotypic correlation coefficients were further partitioned into direct and indirect effects by path analysis as suggested by Dewey and Lu (1959)

\section{Results and Discussion}

The analysis of variance for all the studied characters indicated the plant material is genetically variable. Analysis of variance was presented in the Table 1. Further the material was studied for character association and path coefficient analysis (Table 2, 3 and 4). The genotypic and phenotypic diagrams are presented in Figure 1 and 2.

\section{Days to $50 \%$ flowering}

This trait recorded significant negative correlation with no. of bolls per plant $(-0.289)$ at genotypic level and with bundle strength exhibited significant positive correlation (0.277) at phenotypic level only. It was recorded significant and negative correlation with seed cotton yield $(-0.307)$ at genotypic level. Path coefficient analysis revealed the low direct effect (-0.029) on seed cotton yield but the correlation was high as its indirect negative effects through lint yield was high (0.497) followed by no.of bolls per plant (0.114) at genotypic level only. Hence, selection for this trait leads to reduction in the seed cotton yield. It indirectly reveals that long duration genotypes may leads to high yield. Similar results were also reported by Neelima et al., (2005).

\section{Plant height}

Plant height recorded positive and significant association with lint index $(0.458,0.344)$, ginning out turn $(0.390,0.326)$ at both genotypic and phenotypic levels. No. of bolls per plant (0.194) and lint yield were showed significant positive correlation at genotypic level only. This character recorded positive and non-significant correlation with seed cotton yield $(0.144,0.117)$ at both genotypic and phenotypic level and direct effect of this trait on seed cotton yield also negligible. Selection for this trait may not be leads to considerable increase in the yield. These results are in accordance with the findings of Khan et al., (2015).

\section{No. of monopodia per plant}

This trait recorded significant and negative association with ginning out turn (-0.430, $0.348), 2.5 \%$ span length $(0.543,0.217)$, bundle strength $(0.596,0.264)$ at both genotypic and phenotypic levels. No. of sympodia per plant (-0.278), seed index (0.219), micromaire value (0.494) and uniformity ratio (-0.655) exhibited negative and significant association at genotypic level 
only. This character showed non-significant and very low association with seed cotton yield $(-0.030,0.029)$. Direct effect of this trait on seed cotton yield is very low at both genotypic and phenotypic levels. Selection for this trait may not be considered for increment in the yield. Erande et al., (2014) and Khan et al., (2015) were also reported similar results.

\section{No. of sympodia per plant}

This character recorded significant and positive correlation with boll weight (0.288), lint index (0.288), ginning out turn (0.188), $2.5 \%$ span length (0.349), bundle strength (0.257) and micronaire value (0.490) at genotypic level only. Association with seed cotton yield is very low and non-significant at both genotypic and phenotypic (-0.043, 0.060) levels. Direct effects of this trait were also low both at genotypic and phenotypic ($0.003,0.022$ ) levels. No. of sympodia per plant also not influenced the seed cotton yield as per this study, so that in direct selection process this character also may not be considered. These results are on par with the results of Farooq et al., (2014).

\section{No. of bolls per plant}

No. of bolls per plant exhibited significant and negative with boll weight $(-0.420$, $0.289)$, seed index $(-0.356,-0.260)$ and significant and positive with lint yield $(0.674$, $0.750), 2.5 \%$ span length $(-0.290,-0.190)$. This trait showed positive and significant association with uniformity ratio $(0.267)$ at genotypic level only. Whereas, it was registered significant and positive association with seed cotton yield $(0.780,0.828)$ both at genotypic and phenotypic levels. Direct effect of this trait on seed cotton was negative and high but positive high association was due indirect effects via lint yield (1.236), boll weight (0.107) and lint index (0.090) at genotypic level. At phenotypic level the direct effect is positive. This character may be considered for direct selection for improvement in the seed cotton yield. Similar results were also reported by Kumar et al., (2014) and Ranjan et al., (2014).

\section{Boll weight}

Boll weight recorded significant positive association with seed index $(0.391,0.349)$, lint index (0.405), lint yield $(0.231,0.274)$. Bundle strength (0.189), micronaire value ($0.468)$ and uniformity ratio $(-0.268)$ at genotypic level and with $2.5 \%$ span length (0.233) at phenotypic level. This trait recorded positive and significant association with seed cotton yield $(0.245,0.252)$ at both genotypic and phenotypic levels. Whereas, it showed negative direct effect $(-0.256)$ but correlation is positive due high indirect effects via lint yield (0.424), number of bolls per plant (0.166) and seed index (0.162) at genotypic level.

At phenotypic level the direct was positive (0.059) and low but high association due indirect effects via lint yield (0.283). It reveals that indirect selection through lint yield and boll weight may leads to increase in seed cotton yield. These results are in accordance with findings of Erande et al., (2014) and Khan et al., (2015).

\section{Seed index}

Recorded significant and positive with lint index $(0.603,0.615)$, ginning out turn $(-0.286$, $-0.263), 2.5 \%$ span length $(0.416,0.239)$. Lint yield $(-0.227)$, bundle strength $(0.272)$, micronaire value (-0.580), uniformity ratio (0.220 ). Seed index exhibited negative and low values $(-0.087,-0.050)$ of association with seed cotton yield both at genotypic and phenotypic levels. The direct effects of this trait were high $(0.415,0.084)$ at both genotypic and phenotypic levels respectively. 
Fig.1 Genotypic path diagram

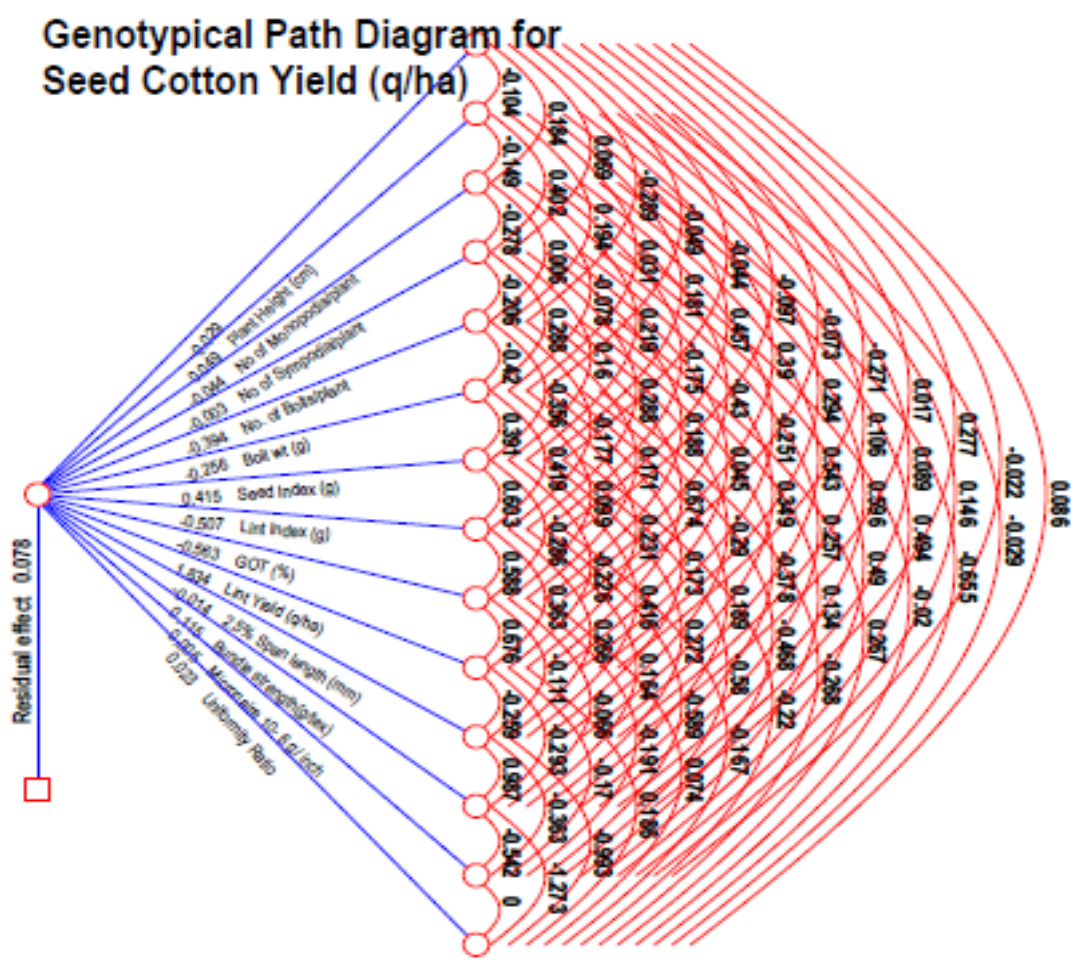

Fig.2 Phenotypic path diagram

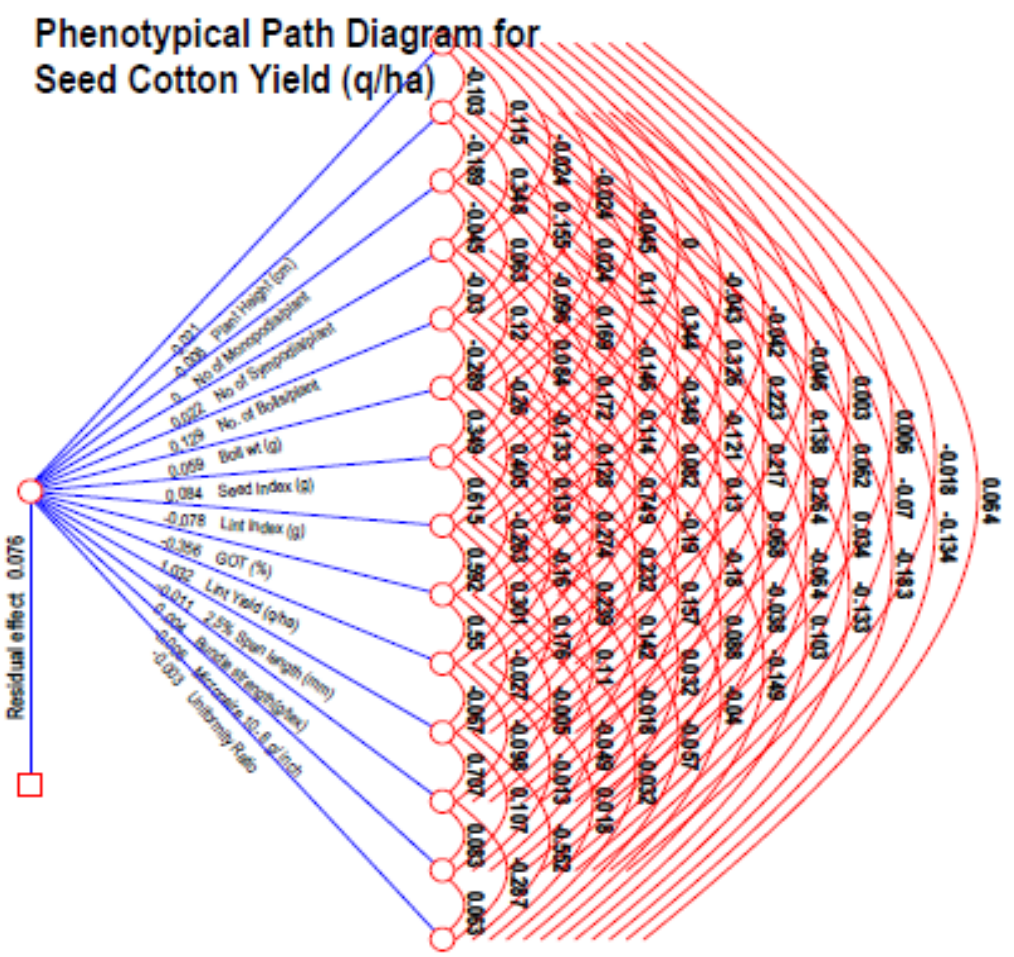


Table.1 Analysis of variance for various quantitative and qualitative characters in upland cotton (Gossypium hirsutum L.)

\begin{tabular}{|c|c|c|c|c|c|c|c|c|c|c|c|c|c|c|c|c|}
\hline Source & Df & DFF & PH & NMP & NSP & NB & BW & SI & LI & GOT & SCY & LY & $2.5 \% \mathrm{SL}$ & BS & MIC & UR \\
\hline Replications & 2 & 20.57 & $2001.00 *$ & $1.64 * *$ & 1.88 & 149.17 & 0.16 & 1.17 & 0.62 & 1.25 & 71.72 & 6.58 & 6.40 & 5.27 & 0.21 & 0.76 \\
\hline Treatments & 36 & $35.75 * *$ & $320.69 * *$ & $0.56 * *$ & $5.58 * *$ & $78.74 * *$ & $0.44 * *$ & $3.80 * *$ & $1.50 * *$ & $18.98 * *$ & $35.41 * *$ & $6.24 * *$ & $5.55^{* *}$ & $4.16^{* *}$ & 0.21 & 3.47 \\
\hline Error & 72 & 11.61 & 43.08 & 0.10 & 2.35 & 15.84 & 0.04 & 0.19 & 0.08 & 0.89 & 11.59 & 1.46 & 1.33 & 1.00 & 0.24 & 2.25 \\
\hline
\end{tabular}

Table.2 Genotypic and phenotypic character association for various traits in cotton (Gossypium hirsutum L.)

\begin{tabular}{|c|c|c|c|c|c|c|c|c|c|c|c|c|c|c|}
\hline & $\begin{array}{c}\text { Dyas to } 50 \\
\% \\
\text { flowering }\end{array}$ & $\begin{array}{l}\text { Plant } \\
\text { Height }\end{array}$ & $\begin{array}{c}\text { No of } \\
\text { Monopodi } \\
\text { a/ } \\
\text { plant }\end{array}$ & $\begin{array}{r}\text { No of } \\
\text { Sympod } \\
\text { ia/ plant }\end{array}$ & $\begin{array}{l}\text { No. of } \\
\text { Bolls/ } \\
\text { plant }\end{array}$ & $\begin{array}{r}\text { Boll } \\
\text { weight }\end{array}$ & $\begin{array}{c}\text { Seed } \\
\text { Index }\end{array}$ & $\begin{array}{c}\text { Lint } \\
\text { Index }\end{array}$ & GOT & $\begin{array}{l}\text { Lint } \\
\text { Yield }\end{array}$ & $\begin{array}{l}2.5 \% \text { Span } \\
\text { length }\end{array}$ & $\begin{array}{l}\text { Bundle } \\
\text { strength }\end{array}$ & $\begin{array}{l}\text { Micronai } \\
\text { re value }\end{array}$ & $\begin{array}{l}\text { Unifor } \\
\text { mity } \\
\text { Ratio }\end{array}$ \\
\hline $\begin{array}{l}\text { Dyas to } 50 \% \\
\text { flowering }\end{array}$ & 1.000 & -0.104 & 0.184 & 0.069 & $-0.289 * *$ & -0.049 & -0.044 & -0.097 & -0.073 & $-0.271 * *$ & 0.017 & $0.277 * *$ & -0.022 & 0.086 \\
\hline Plant Height & -0.103 & 1.000 & -0.149 & 0.402 & $0.194 *$ & 0.032 & 0.181 & $0.458 * *$ & $0.390 * *$ & $0.294 * *$ & 0.106 & 0.089 & 0.146 & -0.029 \\
\hline $\begin{array}{l}\text { No of } \\
\text { Monopodia/plant }\end{array}$ & 0.115 & $-0.189 *$ & 1.000 & $-0.278 * *$ & 0.006 & -0.078 & $0.219 * *$ & -0.175 & $-0.430 * *$ & $-0.251 * *$ & $0.543 * *$ & $0.596^{* *}$ & $0.494 * *$ & $-0.655^{* *}$ \\
\hline No. of Bolls/plant & -0.024 & 0.155 & 0.063 & -0.030 & 1.000 & $-0.420 * *$ & $-0.356 * *$ & -0.177 & 0.171 & $0.674 * *$ & $-0.290 * *$ & $-0.378 * *$ & 0.134 & 0.267 \\
\hline Boll weight & -0.045 & 0.024 & -0.096 & 0.120 & $-0.289 * *$ & 1.000 & $0.391 * *$ & $0.419 * *$ & 0.099 & $0.231 * *$ & 0.173 & $0.189 * *$ & $-0.468 * *$ & $-0.268 * *$ \\
\hline Seed Index & -0.0003 & 0.110 & 0.169 & 0.084 & $-0.260 * *$ & $0.349 * *$ & 1.000 & $0.603 * *$ & $-0.286^{* *}$ & $-0.227 * *$ & $0.416 * *$ & $0.272 * *$ & $-0.580 * *$ & $-0.220^{*}$ \\
\hline Lint Index & -0.043 & $0.344 * *$ & -0.146 & 0.172 & -0.133 & $0.405^{* *}$ & $0.615 * *$ & 1.000 & $0.588 * *$ & $0.364 * *$ & $0.266 * *$ & 0.164 & $-0.589 * *$ & -0.167 \\
\hline GOT & -0.042 & $0.326^{* *}$ & $-0.348 * *$ & 0.114 & 0.128 & 0.139 & $-0.263 * *$ & $0.592 * *$ & 1.000 & $0.677 * *$ & -0.111 & -0.066 & $-0.191 *$ & 0.074 \\
\hline Lint Yield & -0.046 & $0.223^{*}$ & -0.121 & 0.082 & $0.750 * *$ & $0.274 * *$ & -0.160 & $0.302 * *$ & $0.550 * *$ & 1.000 & $-0.259 * *$ & $-0.293 * *$ & -0.171 & 0.186 \\
\hline 2.5\% Span length & 0.003 & 0.138 & $0.217^{*}$ & 0.130 & $-0.190^{*}$ & $0.233^{*}$ & $0.239 *$ & 0.176 & -0.027 & -0.067 & 1.000 & $0.987 * *$ & $-0.363 * *$ & $-0.993 * *$ \\
\hline Micronaire value & -0.018 & -0.070 & 0.034 & -0.064 & -0.038 & 0.088 & 0.032 & -0.018 & -0.049 & -0.013 & 0.107 & 0.083 & 1.000 & 0.0002 \\
\hline Uniformity Ratio & 0.064 & -0.134 & -0.183 & -0.133 & 0.103 & -0.149 & -0.040 & -0.057 & -0.032 & 0.018 & $-0.553 * *$ & $-0.287 * *$ & 0.063 & 1.000 \\
\hline \multirow{2}{*}{$\begin{array}{l}\text { Seed Cotton Yield } \\
\text { (G/P) }\end{array}$} & $-0.307 * *$ & 0.144 & -0.030 & -0.043 & $0.780^{* *}$ & $0.245^{* *}$ & -0.087 & 0.082 & $0.202 * *$ & $0.856^{* *}$ & $-0.250 * *$ & $-0.331 * *$ & -0.149 & 0.172 \\
\hline & -0.014 & 0.117 & 0.029 & 0.0599 & $0.828 * *$ & $0.252 * *$ & -0.050 & 0.080 & 0.168 & $0.913^{* *}$ & -0.070 & -0.112 & 0.000 & 0.036 \\
\hline
\end{tabular}


Table.3 Direct and indirect effect of various characters on seed cotton yield/ha at genotypic level

\begin{tabular}{|c|c|c|c|c|c|c|c|c|c|c|c|c|c|c|}
\hline & $\begin{array}{c}\text { Days to } 50 \\
\% \\
\text { flowering }\end{array}$ & $\begin{array}{l}\text { Plant } \\
\text { Height }\end{array}$ & $\begin{array}{c}\text { No of } \\
\text { Monopodi }\end{array}$ & $\begin{array}{c}\text { No of } \\
\text { Sympodia/ } \\
\text { plant } \\
\text { plant }\end{array}$ & $\begin{array}{l}\text { No. of } \\
\text { Bolls/ } \\
\text { plant }\end{array}$ & $\begin{array}{r}\text { Boll } \\
\text { weight }\end{array}$ & Seed Inde & int Index & GOT & Lint Yield & $\begin{array}{c}2.5 \text { Span } \\
\text { length) }\end{array}$ & $\begin{array}{l}\text { Bundle } \\
\text { strength }\end{array}$ & $\begin{array}{c}\text { Micronaire } \\
\text { value }\end{array}$ & $\begin{array}{c}\text { Uniformity } \\
\text { Ratio }\end{array}$ \\
\hline Days to $50 \%$ flowering & -0.029 & 0.003 & -0.005 & -0.002 & 0.008 & 0.001 & 0.001 & 0.003 & 0.002 & 0.008 & -0.001 & -0.008 & 0.001 & -0.0025 \\
\hline Plant Height & -0.005 & 0.049 & -0.007 & 0.020 & 0.010 & 0.002 & 0.009 & 0.023 & 0.019 & 0.014 & 0.005 & 0.004 & 0.007 & -0.0014 \\
\hline No of Monopodia/plant & -0.008 & 0.007 & -0.044 & 0.012 & -0.000 & 0.003 & -0.010 & 0.008 & 0.019 & 0.011 & -0.024 & -0.026 & -0.022 & 0.0288 \\
\hline No of Sympodia/plant & -0.000 & -0.001 & 0.001 & -0.003 & 0.001 & -0.001 & -0.001 & -0.001 & -0.007 & -0.000 & -0.001 & -0.001 & -0.002 & 0.000 \\
\hline No. of Bolls/plant & 0.114 & -0.077 & -0.002 & 0.081 & -0.394 & 0.166 & 0.140 & 0.070 & -0.068 & -0.266 & 0.114 & 0.149 & -0.053 & -0.105 \\
\hline Boll weight & 0.013 & -0.008 & 0.020 & -0.074 & 0.107 & -0.256 & -0.100 & -0.107 & -0.025 & -0.059 & -0.044 & -0.048 & 0.120 & 0.068 \\
\hline Seed Index & -0.018 & 0.075 & 0.091 & 0.066 & -0.148 & 0.162 & 0.415 & 0.250 & -0.119 & -0.094 & 0.173 & 0.113 & -0.241 & -0.092 \\
\hline Lint Index & 0.049 & -0.232 & 0.089 & -0.146 & 0.090 & -0.212 & -0.306 & -0.507 & -0.298 & -0.184 & -0.135 & -0.083 & 0.299 & 0.085 \\
\hline GOT & 0.041 & -0.219 & 0.242 & -0.106 & -0.096 & -0.056 & 0.161 & -0.331 & -0.563 & -0.381 & 0.062 & 0.037 & 0.107 & -0.042 \\
\hline Lint Yield & -0.497 & 0.539 & -0.461 & 0.082 & 1.236 & 0.424 & -0.415 & 0.667 & 1.240 & 1.834 & -0.475 & -0.538 & -0.313 & 0.342 \\
\hline 2.5 Span length & -0.000 & -0.002 & -0.008 & -0.005 & 0.004 & -0.003 & -0.006 & -0.004 & 0.002 & 0.004 & -0.014 & -0.014 & 0.005 & 0.014 \\
\hline Bundle strength & 0.032 & 0.010 & 0.069 & 0.030 & -0.044 & 0.022 & 0.031 & 0.019 & -0.008 & -0.034 & 0.114 & 0.115 & -0.062 & -0.147 \\
\hline Micronaire value & -0.000 & 0.001 & 0.002 & 0.002 & 0.001 & -0.002 & -0.003 & -0.003 & -0.010 & -0.001 & -0.002 & -0.003 & 0.005 & 0.000 \\
\hline Uniformity Ratio & 0.002 & -0.001 & -0.015 & -0.001 & 0.006 & -0.006 & -0.005 & -0.004 & 0.002 & 0.004 & -0.023 & -0.029 & 0.000 & 0.023 \\
\hline Seed Cotton Yield & -0.307 & 0.144 & -0.030 & -0.043 & 0.780 & 0.245 & -0.087 & 0.082 & 0.202 & 0.856 & -0.250 & -0.331 & -0.149 & 0.172 \\
\hline
\end{tabular}

Diagnol values are direct effects

Residual value $=0.078$

Table.4 Direct and indirect effect of various characters on seed cotton yield/ha at phenotypic level 


\begin{tabular}{|c|c|c|c|c|c|c|c|c|c|c|c|c|c|c|}
\hline & $\begin{array}{l}\text { Days to } 50 \% \\
\text { flowering }\end{array}$ & Plant Height & $\begin{array}{c}\text { No of } \\
\text { Monopodia/ } \\
\text { plant }\end{array}$ & $\begin{array}{c}\text { No of } \\
\text { Sympodia/ } \\
\text { plant }\end{array}$ & $\begin{array}{l}\text { No. of } \\
\text { Bolls/ } \\
\text { plant }\end{array}$ & Boll weight & $\begin{array}{c}\text { Seed } \\
\text { Index }\end{array}$ & Lint Index & GOT & Lint Yield & $\begin{array}{l}\text { 2.5\% Span } \\
\text { length }\end{array}$ & $\begin{array}{c}\text { Bundle } \\
\text { strength }\end{array}$ & $\begin{array}{l}\text { Micronaire } \\
\text { value }\end{array}$ & $\begin{array}{c}\text { Uniformity } \\
\text { Ratio }\end{array}$ \\
\hline Days to $50 \%$ flowering & 0.021 & -0.002 & 0.003 & -0.001 & -0.001 & -0.001 & 0.000 & -0.001 & -0.001 & -0.001 & 0.000 & 0.000 & -0.000 & 0.001 \\
\hline Plant Height & 0.001 & -0.006 & 0.001 & -0.002 & -0.001 & -0.000 & -0.001 & -0.002 & -0.002 & -0.001 & -0.001 & -0.000 & 0.000 & 0.001 \\
\hline No of Monopodia/plant & 0.000 & -0.000 & 0.000 & 0.000 & 0.000 & 0.000 & 0.000 & -0.000 & -0.000 & 0.000 & 0.000 & 0.000 & 0.000 & -0.000 \\
\hline No of Sympodia/plant & -0.001 & 0.008 & -0.001 & 0.022 & -0.001 & 0.003 & 0.002 & 0.004 & 0.003 & 0.002 & 0.003 & 0.002 & -0.001 & -0.003 \\
\hline No. of Bolls/plant & -0.003 & 0.020 & 0.008 & -0.004 & 0.129 & -0.037 & -0.034 & -0.017 & 0.017 & 0.097 & -0.025 & -0.023 & -0.005 & 0.013 \\
\hline Boll weight & -0.003 & 0.001 & -0.006 & 0.007 & -0.017 & 0.059 & 0.021 & 0.024 & 0.008 & 0.016 & 0.014 & 0.009 & 0.005 & -0.009 \\
\hline Seed Index & 0.000 & 0.009 & 0.014 & 0.007 & -0.022 & 0.029 & 0.084 & 0.052 & -0.022 & -0.013 & 0.020 & 0.012 & 0.003 & -0.003 \\
\hline Lint Index & 0.003 & -0.027 & 0.011 & -0.014 & 0.011 & -0.032 & -0.048 & -0.078 & -0.047 & -0.024 & -0.014 & -0.009 & 0.001 & 0.005 \\
\hline GOT & 0.015 & -0.116 & 0.124 & -0.041 & -0.046 & -0.049 & 0.094 & -0.211 & -0.356 & -0.196 & 0.010 & 0.002 & 0.018 & 0.011 \\
\hline Lint Yield & -0.048 & 0.231 & -0.125 & 0.085 & 0.774 & 0.283 & -0.165 & 0.311 & 0.568 & 1.033 & -0.069 & -0.101 & -0.013 & 0.018 \\
\hline $2.5 \%$ Span length & 0.000 & -0.002 & -0.003 & -0.002 & 0.002 & -0.003 & -0.003 & -0.002 & 0.000 & 0.000 & -0.011 & -0.008 & -0.001 & 0.006 \\
\hline Bundle strength & 0.000 & 0.000 & 0.001 & 0.000 & -0.001 & 0.001 & 0.001 & 0.001 & 0.000 & -0.000 & 0.003 & 0.004 & 0.000 & -0.001 \\
\hline Micronaire value & 0.000 & 0.000 & -0.000 & 0.000 & 0.000 & -0.001 & -0.000 & 0.000 & 0.000 & 0.000 & -0.001 & -0.001 & -0.006 & -0.000 \\
\hline Uniformity Ratio & -0.000 & 0.000 & 0.001 & 0.000 & -0.000 & 0.001 & 0.000 & 0.000 & 0.000 & -0.000 & 0.002 & 0.001 & -0.000 & -0.003 \\
\hline Seed Cotton Yield & -0.014 & 0.117 & 0.029 & 0.0599 & 0.828 & 0.252 & -0.050 & 0.080 & 0.168 & 0.913 & -0.070 & -0.112 & 0.000 & 0.036 \\
\hline
\end{tabular}


The negative association was due to high and negative indirect effects through lint yield ($0.415)$, lint index (-0.306) and boll weight ($0.100)$ at genotypic level, at phenotypic level the direct is low (0.084) and positive but indirect effects through lint yield $(-0.165)$ and lint index (-0.048) were high and negative. Here restriction may put on lint yield and lint index and selection for this trait may leads to increase in seed cotton yield. Rajanna et al., (2011) also reported similar findings.

\section{Lint index}

Ginning out turn $(0.588,0.592)$, lint yield per plant $(0.364,0.302)$ at both. $2.5 \%$ span length (0.266), micronaire value $(-0.589)$ at genotypic level only. Lint index recorded positive and non-significant association with yield $(0.082,0.080)$ both at genotypic and phenotypic levels. This trait showed negative direct effects at both genotypic (-0.507) and phenotypic (-0.078) levels respectively but the positive association was due to indirect effects through other yield contributing characters. Direct selection for this trait may not be result in increased yield and indirect selection through other characters may be fruitful. Similar findings were also reported by Erande et al., (2014), Ranjan et al., (2014) and Khan et al., (2015).

\section{Ginning out turn}

Ginning out turn registered significant and positive association with lint yield per plant $(0.677,0.550)$, micronaire value $(-0.191)$ at genotypic level. This trait showed positive and significant association with seed cotton yield at genotypic level (0.202) and positive and non-significant at phenotypic level. The direct effect of this trait on seed cotton yield was negative and high $(-0.563)$ but positive association was recorded due to high indirect effects through lint yield (1.240) at genotypic level. At phenotypic level recorded negative direct effect $(-0.356)$ but positive association due to high indirect effects trough lint yield (0.568). Direct selection may be recommendable for this trait for improving seed cotton yield. These findings are in accordance with the results of Erande et al., (2014) and Farooq et al., (2014).

\section{Lint yield}

Significant and positive correlation with $2.5 \%$ span length (-0.259) and bundle strength (0.293 ) at genotypic level. This trait showed high and positive association with seed cotton yield at both genotypic and phenotypic levels $(0.856,0.913)$. The direct effect of this trait on seed cotton yield was high and positive at both genotypic and phenotypic levels (1.834, 1.033). Direct selection for this trait may leads to increase in the seed cotton yield. Erande et al., (2014) and Rajanna et al., (2011) also reported similar findings.

\section{$2.5 \%$ span length}

Significant and positive correlation with bundle strength $(0.987,0.707)$ and uniformity ratio $(-0.993,-0.287)$ and micronaire value ($0.363)$ at genotypic level only. This character exhibited negative and significant at genotypic (-0.250) level and negative and non-significant at phenotypic (-0.070) level. The direct effects of this trait on seed cotton were negative at both genotypic and phenotypic level $(-0.014,-0.011)$. Direct selection for this trait may be leads decrease in seed cotton yield. Vinodhana et al., (2013) also reported similar results.

\section{Bundle strength}

This character exhibited significant and negative correlation with micronaire value ($0.547)$ at genotypic level and with uniformity ratio (-0.287) at phenotypic level. Negative and significant correlation recorded with seed 
cotton yield (-0.331) at genotypic level and negative and non-significant association (0.112) at phenotypic level recorded. Direct effects of this trait on seed cotton yield were positive $(0.115,0.004)$ but negative association was due to indirect effects through lint yield $(-0.538,-0.101)$ at both genotypic and phenotypic levels. By restricting characters like lint yield and selection for this trait may be leads to increase in seed cotton yield. These results are similar with findings of Vinodhana et al., (2013).

\section{Micronaire value}

Micronaire value recorded significant and negative association with bundle strength (0.547) at genotypic level only. This trait recorded very low values of association with seed cotton yield at both genotypic and phenotypic $(-0.149,0.000)$ levels. Direct effects of this trait on seed cotton yield were also very low. Direct selection for this trait may not be influence the considerable change in the seed cotton yield. Similar results were also reported by Farooq et al., (2014).

\section{Uniformity ratio}

Uniformity ratio recorded positive and nonsignificant association with seed cotton yield $(0.172,0.036)$ at both genotypic and phenotypic levels. The direct effects of this trait on seed cotton yield were also very low. Direct selection for this trait may not be considerable influence the change in the seed cotton yield. These results are in accordance with the findings of Kishore et al., (2011).

The path analysis indicated that lint yield plant $^{-1}$ showed high direct positive effect and significant correlation with seed cotton yield, no. of bolls per plant and boll weigh also recorded significant association but direct effects were low. It indicates restriction selection is advisable for getting improvement in the yield. In plant breeding, it is very difficult to have complete knowledge of all component traits of yield. The residual effect permits precise explanation about the pattern of interaction of other possible components of yield. In other words, residual effect measures the role of the possible independent variables which were not included in the study on the dependent variable. In the present study, the residual effect observed was low both at phenotypic (0.076) and genotypic (0.078) levels, so the characters included in the study clearly explained the direct and indirect effects on the dependent variable.

\section{References}

Bayyapu Reddy, K., Chenga Reddy, V., Lal Ahmed, M., Naidu, T.C.M and Srinivasarao, V. 2015. Correlation and Path Coefficient Analysis in Upland Cotton (Gossypium hirsutum L.). Intenational Journal of Pure and Applied Biosciences. 3 (3): 70-80.

Dewey, D.R and Lu, K.H. 1959. A correlation and path coefficient analysis of components of crested wheat grass seed production. Agronomy Journal. 51(9): 515-518

Erande, C.S., Kalpande, H.V., Deosarkar, D.B., Chavan, S.K., Patil, V.S., Deshmukh, J.D., Chinchane, V.N., Kumar, A., Utpal, D and Puttawar, M.R. 2014. Genetic variability, correlation and path analysis among different traits in desi cotton (Gossypium arboreum L.). African Journal of Agricultural Research. 9(29): 2278-2286.

Farooq, J., Anwar, M., Riaz, M., Farooq, A., Mahmood, A., Shahid, M.T.H., Rafiq, M.S and Ilahi, F. 2014. Correlation and path coefficient analysis of earliness, fiber quality and yield contributing traits in cotton (Gossypium hirsutum L.). The Journal of Animal and Plant 
Sciences. 24(3): 781-790.

Khan, F.Z., Rehman, S.U., Abid, M.A., Malik, W., Hanif, C.M., Bilal, M., Qanmber, G., Latif, A., Ashraf, J and Farhan, U. 2015. Exploitation of germplasm for plant yield improvement in Cotton (Gossypium hirsutum L.). Journal of Green Physiology, Genetics and Genomics. 1(1): 1-10.

Kishore, K.D., Gopinath, M., Satyanarayana Rao, V and Srinivasa Rao, V. 2011. Genetic variability studies in upland cotton. The Andhra Agricultural Journal. 58(1): 17-21.

Kumar, S.P., Siwach, S.S., Sangwan, R.S., Sangwan, O and Deshmukh, J. 2014. Correlation and path coefficient analysis for yield and fibre quality traits in upland cotton (Gossypium hirsutum L.). Journal of Cotton Research and Development. 28(2): 214-216.

Neelima, S., Chenga Reddy, V and Narisireddy, A. 2005. Association and path analysis in American cotton (Gossypium hirsutum L.). Journal of the
Indian Society for Cotton Improvement. 30(1): 53-58.

Rajanna, B., Samba Murthy, J.S.V., Lal Ahamed, $M$ and Srinivasa Rao, V. 2011. Correlation and path coefficient analysis in upland cotton (Gossypium hirsutum L.). The Andhra Agricultural Journal. 58(2): 151-155.

Ranjan, R., Sangwan, R.S., Siwach, S.S., Sangwan, O and Sah, M.K. 2014. Correlation and path analysis studies in Gossypium arboreum L. Journal of Cotton Research and Development. 28(1): 37-39.

Singh, R.K and Chaudhary, B.D. 1985. Biometrical Methods in Quantitative Genetic Analysis. Kalyani Publishers, New Delhi. 205-214.

Vinodhana, K.N., Gunasekaran, $\mathrm{M}$ and Vindhyavarman, P. 2013. Genetic studies of variability, correlation and path coefficient analysis in cotton genotypes. International Journal of Pure and Applied Bioscience. 1(5): 610.

\section{How to cite this article:}

Siva Reddy, K.V., B. Balakrishna and Chenga Reddy, V. 2019. Study of Cause and Effect Relationship among Yield, Yield Contributing and Quality Traits in Cotton (Gossypium hirsutum L.). Int.J.Curr.Microbiol.App.Sci. 8(06): 1798-1807.

doi: https://doi.org/10.20546/ijcmas.2019.806.215 